\title{
Exploring the Socio-economic Effects of the Community Tourism Fund to the Local Community, Maasai Mara National Reserve
}

\author{
Mark Lari Letoluo", Lawrence Wangombe \\ Hospitality and Tourism Department, Mount Kenya University, Kenya
}

Copyright $(2018$ by authors, all rights reserved. Authors agree that this article remains permanently open access under the terms of the Creative Commons Attribution License 4.0 International License

\begin{abstract}
This study evaluates the socio-economic effects of tourism development on the local community in Narok County, Kenya. It uses descriptive and inferential statistics, the county wants to utilize tourism as an economic development tool to reduce poverty and increase socio-economic wellbeing. Tourism has profound effects on the local community of the destination as it brings economic and socio-cultural changes. Some of the positive economic impacts include; increased direct and indirect employment, enhanced standard of living, more investments, infrastructural development, and new business linkages and opportunities. Some of the identified negative economic impacts include, increased income disparity, increased land price and rent, price hike of essential goods and services, seasonality effects and leakage of earnings. From the findings majority of the tourism assets and well-paid jobs are enjoyed by nonlocal whereas the local community does not benefit its rightful share due to uneven benefit distribution. Major positive socio-cultural impacts include: increased women participation and empowerment, increase in the level of education, enhanced social security and safety. Some negative socio-cultural impacts are grabbing of land from the poor, increased social gap, social disorder and loss of cultural originality. The local community is involved in tourism activities but are not fully involved in the decision making process. This study reveals that the local community is not fully involved in policy formulation process and most stake holders do not consider the socio-economic impacts of tourism development on the local community. Some recommendations are made for the Development of Tourism in Narok County to maximize positive impacts and minimize negative impacts.
\end{abstract}

Keywords Community Tourism Fund, Tourism, Local Community

\section{Introduction}

Tourism is one of the fastest growing sectors in the world by a continuous increase in visitor population, high level of direct and indirect employment and billons in investments. According to WTTC, (2015), Travel and tourism contributed to USD 7,580bn in 2014 and is projected to increase by 3.8 pa to USD 11,381 bn in 2015 . It also contributed to $277 \mathrm{bn}$ jobs, and is expected to rise up to $357 \mathrm{bn}$ jobs in 2025. In this current market USD 814bn and is expected to rise to USD 1,336bn in 2015. According to regions, Europe, the Americas and Asia and the Pacific all recorded approximately 5\% growth in 2015 . Arrivals in the Middle East increased by 3\% while data in Africa, albeit limited, pointed to an estimated 3\% decrease. (UNWTO, 2015).

According to the African development bank (2015), Tourism continued to be one of the fastest growing economy despite challenges, including Ebola outbreak in West Africa, it's still one of the highest job creators in Africa. In 2014, arrivals increased in Africa by 200,000 over the previous year, this includes $5 \%$ visitor increase in Egypt equating to 454,000 more visitors while morocco, maintained its recording of surpassing 10 million arrivals for the second consecutive year. Côte d'Ivoire showed an increase of $24 \%$ in arrivals of about 91,000 more visitors in 2014 as compared to the previous year. Some of the growth is attributed to progress made by countries and regions, including the implementation of East African Community (EAC) visa and the Southern African Development Community (SADC) KAZA visa between Zimbabwe and Zambia.

Tourism is an important sector in Kenya and accounts for over 13\% of the Gross Domestic Product (GDP) making it the third largest contributor after agriculture and manufacturing and third foreign exchange earner after tea and horticulture. The direct contribution of Travel \& Tourism to GDP in 2014 was KES220.6bn (4.1\% of GDP). 
(WTTC, 2015). According to (Government of Kenya, 2007) vision 2030, Kenya seeks to become one of the premier long-haul destinations, this is attaining to the fact that tourism accounts for close to 10 per cent of Kenya's GDP and 9 per cent of total formal employment. This means that Kenya is rigorously marketing itself in the international with the current budget of $4.5 \mathrm{bn}$ being set aside for the sector. According to (Bhandari \& Phd, 2014), Tourism within Kenya is found to be very successful in terms of economic benefit. The natural beauty and the existence of an abundance of wildlife attract many tourists from the developed world. Tourists like to come and see the wildlife, beautiful beaches and the moderate weather. $\mathrm{He}$ also argued that tourism has great socio-economic influence on the Kenyan Government, especially in poverty eradication and sustainable development. In premier parks and reserves most of the local community depend on tourism related activities as the major source of income, Maasai Mara National Reserve (MMNR) is not an exception with a high number of surrounding local community it is therefore vital to cross examine the benefits especially economic and social, in fostering cohesion and good will to the industry. (NCG, 2015).

The Constitution has assigned the county level responsibility for trade development and regulation, including - markets; trade licenses (excluding regulation of professions); fair trading practices; local tourism; and cooperative societies. Therefore, the county level will be responsible for implementation of the national policies and related activities meant to deliver the services behind these functions at the county level. (NCG, 2015)

Narok County is one of the Kenya's top tourist destinations. As a county, it hosts Maasai Mara Game Reserve, commonly known as the Seven Wonder of the world, the epitome of the Wildebeest Migration world's diverse wildlife, it also homes the Maasai community respected for their pride in their beautiful culture. Despite the fact of immense richness, it is ranked at $41 \%$ below poverty line with the local community suffering from human wildlife conflict and not benefiting from the tourism revenue. This prompted to the setting up of the Community tourism fund that is $19 \%$ of all revenue collected from the Maasai Mara National Reserve which will be devoted to support the communities in Narok County on issues such as conservation, infrastructural development, wealth creation and in fight against poverty and county functions under the Fourth Schedule of the Constitution of Kenya at Ward Level. The percentage will be calculated on the basis of the park entry fee as in the audited financial statement of the preceding year. (NCG, 2014). It is in this context that this study was conceived to find out the contribution of community tourism fund to the local people's livelihoods.

The research was to explore the Socio-Economic Effects of the Tourism Revenue to the Local Community, Maasai Mara National Reserve. Some of the objectives included: 1. Establish the relationship between investments and socio-economic effects of tourism 2. Investigate how infrastructure development is related to socio-economic effects of tourism 3 Examine ways in which leisure and recreation affects tourism 4 . Assess the extension in which educational research affects socio-economic status of the county.

The importance of carrying out this study is to explore tourism revenue's economic and socio-cultural effects. This will be used by the local Government, private sector, local community and researchers to assisting in finding amicable solutions to pertinent issues affecting tourism and its related activities.

\section{Literature Review}

\subsection{Sustainable Tourism and Community Development}

The importance of developing tourism sustainably has gained increasing attention in recent years. Sustainable tourism is defined by Badan \& Bhatt (2007) as tourism "that is developed and maintained in a manner, and at such a scale, that it remains economically viable over an indefinite period and does not undermine the physical and human environment that sustains and nurtures it". Tourism development has frequently been identified as an important vehicle for regions or countries to grow economically (Kim, Uysal, \& Sirgy, 2012).

The enhancement of living conditions and community well-being can be achieved in myriad ways. According to Fennell (1999) and Okazaki (2008), CBD can improve the quality of life for local residents by providing them with employment, the possibility of ownership of their own businesses, social capital creation, and stronger cultural awareness. Roseland (2005) supports these views by stating that community participation should enable locals "to shape their local economies by influencing the type of business, industry, and employment opportunities in their own backyards". Indeed, Sebele (2010) and Tosun (2006) have argued that community participation will often ensure sustainability, as locals develop positive attitudes to the very environments that provide them with jobs and financial resources.

According to Nyaupane and Poudel (2011), local communities that have been overlooked or marginalized during the planning stage of tourism development will frequently withdraw their support of the protection of natural environments. Sebele (2010) argues that this scenario is often fostered by a community's assumption that tourism development without their input "will not reflect their values". Hall and Richards (2000) also concur, stating "disadvantaged local communities may not be able to identify with tourism development because they view it as an exogenous development with benefits that largely accrue to outsiders... [an] inability to identify with tourism development in turn may lead either to resistance or 
indifference". Thus, based on the majority of outcomes observed in other studies, local community involvement during the planning stage is of significant importance to successful implementation. As Hall and Richards (2000) and McGehee and Andereck (2004) all suggest, a local community's perception and understanding of tourism development is crucial and it is also imperative that they understand the consequences as well as the benefits.

\subsection{The Impacts of Tourism Development}

According to Sherman and Dixon (1991), positive social impacts can be described as "broadly as any gains in social welfare, either direct or indirect... such gains may be either financial in nature or nonmonetary". One must therefore assume that negative social impacts must entail a range of opposite processes. Examples of positive social impacts are provided by Meyer (2006), who observed that the benefits could include the development of new capacity (i.e. employees completing studies or qualifications specific to tourism), improved local infrastructure, and supplier support that entails the training of those employed in supporting businesses. Kim, Uysal and Sirgy (2012) have specifically noted the positives of infrastructural change which, they argue, produces distinctive social benefits

Thus, the social benefits initiated by tourism can therefore be extensive in scope and present a range of outcomes that exceed economic gain. Although Sherman and Dixon (1991) acknowledge that tourism, if implemented correctly, may stimulate the economy by providing jobs and markets for local goods, they argue that regional or national governments must take heed of these additional benefits, stating "while government officials may be primarily interested in the amount of expenditures and employment opportunities generated, they also should be aware of the larger picture - that is, the social benefits associated with nature tourism".

\subsection{Tourism Development, Poverty Relief and Empowerment}

As discussed earlier in this study, tourism has been identified as a vehicle to reduce poverty in developing nations. Indeed, the notion of "pro-poor" tourism (Hall \& Page, 2009; Meyer, 2007; Rogerson \& Pillay, 2013; Rogerson \& Rogerson, 2010) has garnered increasing attention in a plethora of recent studies. However, although tourism has been identified as a solution to poverty alleviation, numerous examples reveal that high leakages (caused by high numbers of foreign business developments) will often result in little to no improvement in the reduction of poverty amongst communities (Blake, Arbache, Sinclair, $\&$ Teles, 2008). As Sandbrook posits (2010), leakages are caused "when revenue leaves the destination as profit to non-local businesses or for the purchase of external goods and services". Therefore, economic growth does not necessarily result in enhanced social benefits. Park and Stokowski $(2009$,) noted that even in scenarios whereby tourism development resulted in the creation of new jobs, many were filled with foreign nationals or non-local residents, as opposed to members of the immediate community. Moreover, the notion of pro-poor tourism presents other contentious issues as "local people may not want to be labelled in a way that portrays them as helpless, miserable, and primitive" (Nyaupane \& Poudel, p. 2011, 1348). Similarly, citing the observations of Pfohl (1994), Nyaupane \& Poudel, 2011, argue that such terms may portray the poor as "abnormal losers", and instead terms such as, "livelihood improvement" should be preferred over "poverty reduction." Nonetheless, Hall and Page (2009) suggest that poverty reduction and pro-poor tourism have emerged to become "key considerations for the future of international tourism management". According to McCulloch (2001) poverty is a term that is attributed to those who earn low incomes or are unemployed, have limited or no education, and frequently reside in areas or environments of poor quality. Scoones (1998) argues that poverty is not simply a case of lacking financial resources but social resources too, including access to clean and pleasant environments. In order for poverty reduction to be achieved, Nyaupane \& Poudel, (2011) argue that community "empowerment" is an intrinsic theme that not only includes economic factors but social factors too.

Citing the views of Friedmann (1992) and Scheyvens (1999), Nyaupane \& Poudel (2011) suggest that the notion of empowerment "is a multi-dimensional concept including economic, social, political, and psychological empowerment". Members of a community may be economically empowered through formal or informal sector employment and via the development of new businesses. Economic empowerment may also enable communities to improve their own livelihoods by developing better infrastructure and by increasing access to education or health care (Nyaupane \& Poudel, 2011). However, other modes of empowerment may entail a plethora of additional advantages. This may include "social empowerment", whereby communities become more cohesive as they pull together, and "psychological empowerment" which includes the development of selfesteem amongst community members (Nyaupane \& Poudel, 2011; Scheyvens, 1999).

\subsection{Research and Education}

The range of visitor needs for research and education is too broad for a comprehensive discussion here, but in short it includes both formal and informal education of tourists and even entire societies. However, there is a real need for professionals to collect and draw upon primary data so that education can be geared to a particular target group and encompass the needs of the hosts (Smith, 2003). Urry, (2002), says "This would offer visitors the chance to learn 
about the community, or give them the opportunity to learn something about the significance of a place and its association with the local community, its heritage and a cultural or natural landscape".

\subsection{Methodology}

This study uses descriptive and inferential statistics according to (Allan 2004) descriptive statistics is a process of collecting data in order to consider and explain questions concerning the current status of the subject in the study he further says that descriptive research determines and reports the way things are. All describes inferential statistics as a branch of statistics which the researcher will use to draw conclusions about a given phenomenon in population. Its purpose is to enable the researcher to generalize his results from a sample of the population.

The study was therefore carried out in Narok County. The county is sparsely populated especially the rural areas with a large number of illiterate people. The area of interest will be around MMNR where the premier park is located and within Narok County Offices, in Narok Town. The county experiences average High/Low temperature and two rainy seasons a year march to April and October to December. The roads are mostly dusty and impassable especially during rainy season with a lot of potholes. The county is occupied by Maasai and Kalenjin communities with non Maasai's and Kalenjin's residing in towns and shopping centers.

\subsection{Target Population}

\begin{tabular}{|c|c|c|c|c|c|}
\hline \multirow{2}{*}{ CATEGORY } & \multicolumn{4}{|c|}{ LOCATION } & \multirow{2}{*}{ POPULATION } \\
\hline & TALEK & SIKINANI & MUSIARA & OLOOLAIMUTIA & \\
\hline Private sector & 5 & 5 & 5 & 5 & 20 \\
\hline Local community & 10 & 10 & 10 & 10 & 40 \\
\hline Government rep & 5 & 5 & 5 & 5 & 20 \\
\hline Total & 20 & 20 & 20 & 20 & 80 \\
\hline
\end{tabular}

Source: Researcher, (2016)

\section{Data Analysis, Findings and Interpretation}

\subsection{Introduction}

In this chapter the data collected and explored is analyzed and presented in appropriate forms depending on the type of data and details contained. The research questions and objectives are used as basics for the presentation and the findings are also discussed. The response rate managed was 75 out of 80 questionnaires were obtained that is $93.75 \%$.

\subsection{Investments}

Table 1. Effects of investments to tourism

\begin{tabular}{|c|c|c|}
\hline Effects & Frequency & Percentage \\
\hline Employment & 8 & 16.7 \\
\hline Entrepreneurship development & 7 & 12.5 \\
\hline Control of Tourism assets by non-local people & 12 & 25 \\
\hline Leakage & 12 & 25 \\
\hline Low paid Job for Local people & 10 & 20.8 \\
\hline
\end{tabular}

Source: Researcher (2016)

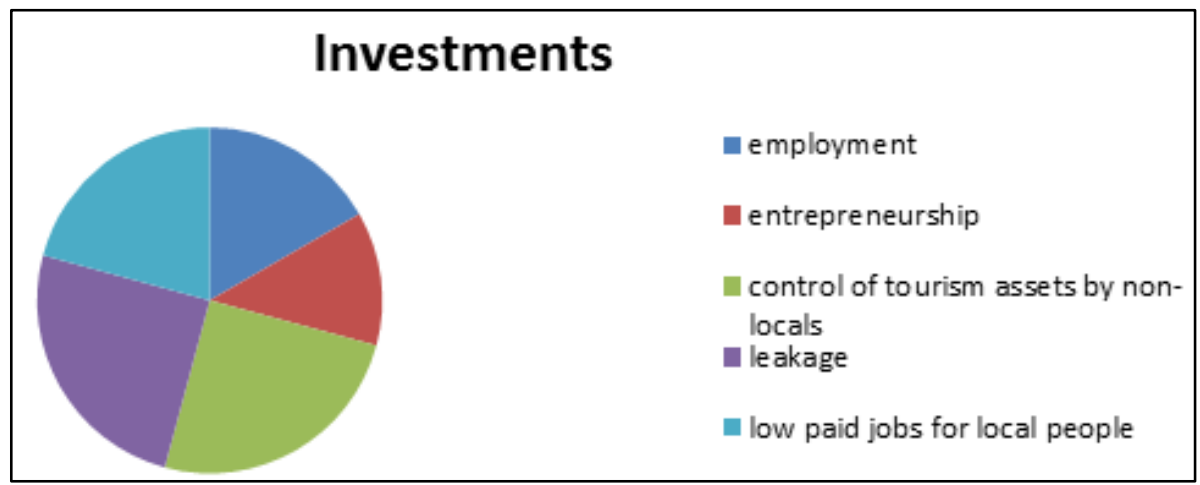

Figure 1. Effects of investments to tourism 
Figure above shows how investments affect tourism with a majority of the respondents feeling dissatisfied with the huge control of tourism assets by non-locals, leakages and low paid for local people. This problem is caused by the owners/investors who are mainly from, America, Europe, and Asia among others. Locals work for many hours from the construction of the camps and lounges to providing services with little remuneration and holidays, this is mainly due to the level of education of the locals and lack of clear control and regulation from the county government living the locals in the mercies of their bosses.

\subsection{Infrastructure Development}

Table 2. Effects of infrastructure development to tourism

\begin{tabular}{|c|c|c|}
\hline Effects & Frequency & Percentage \\
\hline Improved standard of living & 23 & 50 \\
\hline Loss of land & 7 & 16.67 \\
\hline Displacement of the poor from their land & 15 & 33.33 \\
\hline
\end{tabular}

Source: Researcher (2015)

\section{Infrastructure development}

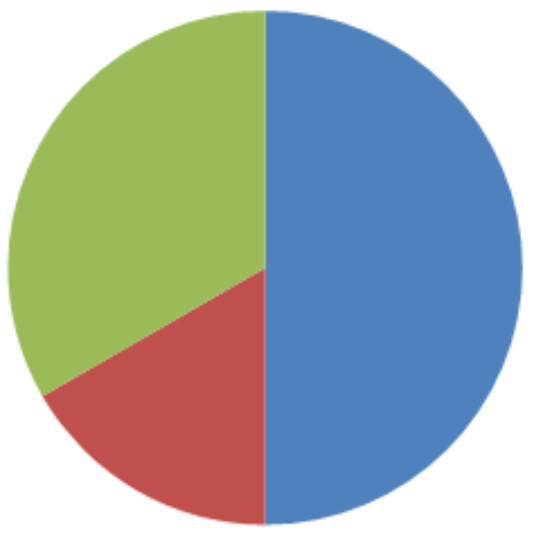

- improved standards of living

- loss of land

a displacement of the poor from the ir land

Figure 2. Effects of infrastructure development to tourism

From the above shows how infrastructure development has resulted to displacing the poor from their lands either for expansion purposes or for greed and corruption mainly contributed by the lack of clear land marking and title deeds. Also a significant percentage felt that infrastructure development has positively impacted their lives ranging from the carpeting of roads, to schools constructed by the private sector and health facilities which have made the quality of live to be improved and access to basic needs improved. A relatively few number felt locked out especially the youth and women from the acquisition of land to private developers to the sale of land by the men without consulting their families.

\subsection{Leisure and Recreation}

Table 3. Effects of leisure and recreation to tourism

\begin{tabular}{|c|c|c|}
\hline Effects & Frequency & Percentage \\
\hline Increased income & 7 & 20.8 \\
\hline Dependency & 4 & 12.5 \\
\hline High price of commodities & 11 & 25 \\
\hline Limited outward migration & 2 & 5 \\
\hline Promotion of traditional handicrafts and artifacts & 6 & 8.3 \\
\hline Increased safety and security & 3 & 3.3 \\
\hline Commodification of arts and culture & 6 & 15 \\
\hline Increased women empowerment & 4 & 10 \\
\hline
\end{tabular}

Source: Researcher (2016) 


\title{
Leisure and Recreation
}

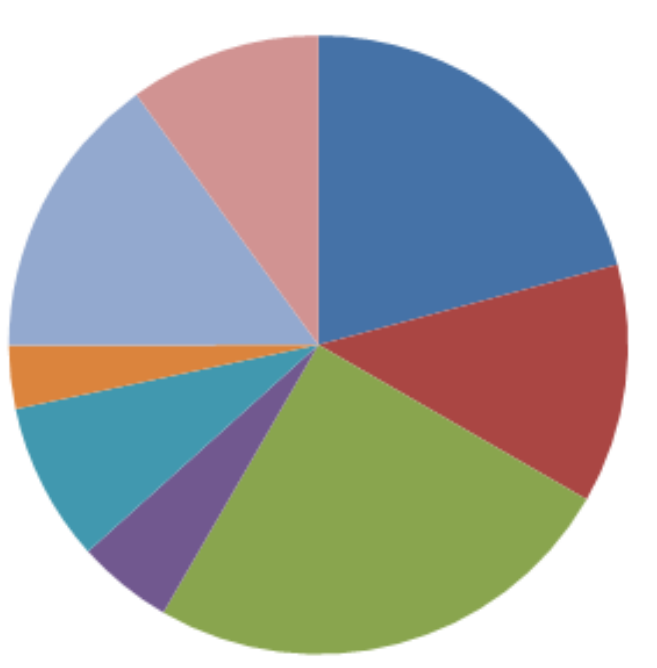

\author{
income \\ dependency \\ high price of com modities \\ Limited Outward Migration \\ - Promotion of traditional \\ handicrafts and art ifacts \\ Increased safety and security \\ commodification of arts and \\ culture \\ increased woman \\ empowerment
}

Figure 3. Effects of leisure and recreation to tourism

From the above findings leisure and recreation activities have resulted in high prices of commodities and inflation. Income is relatively high from the visitation of the tourists to reserve and to local manyattas where many locals engage in entertaining the visitors. Another problem is the high dependency rate of tourism activities by the locals who many depend on tourism and livestock rearing since the lands cannot be used for agricultural purposes especially during low seasons. Also there is a significant concern about commodification of arts of culture with locals feeling infringement of private space by other people from places like central and Nairobi where most of their original work of art and unique cultural pattern is pirated and sold to tourists as souvenirs. Through leisure and recreation there has been promotion of traditional handicrafts and artifacts, empowerment of women and limited outward migration of the locals to neighboring counties.

\subsection{Educational Research}

Table 4. Effects of educational research to tourism

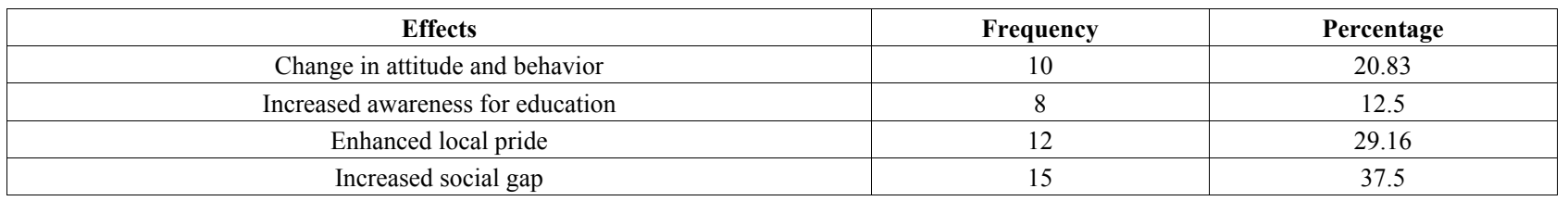

Source: Researcher (2016)

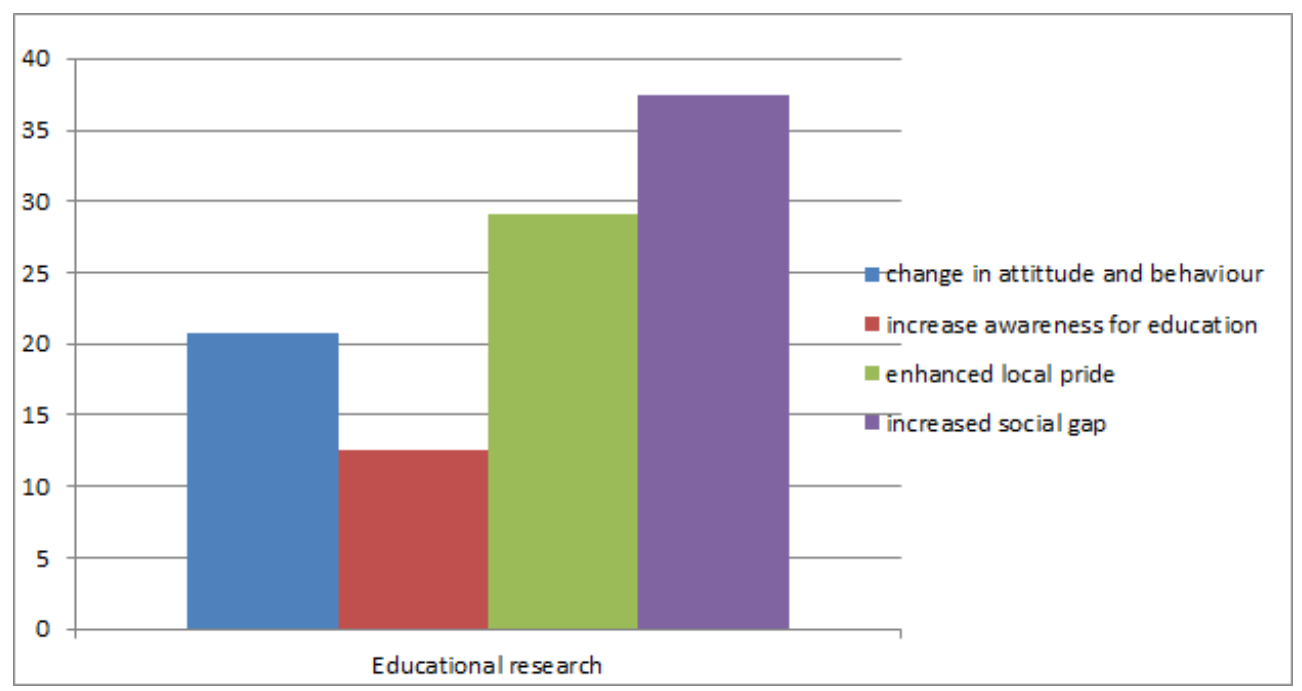

Figure 4. Effects of educational research to tourism 
From the above figure educational research has resulted into an increase in social gap especially for the learned people who get privileged to get scholarships to study abroad and generally the people directly involved in tourism activities who usually start criticizing the original and native way of life. A significant number felt that educational research has enhanced local pride in assisting them learn foreign languages and by conducting research, researchers usually increase education awareness and significant while improving and changing the attitude and behavior of locals towards tourism and tourism related activities.

\section{Summary}

The study reveals how investments, infrastructure development, leisure and recreation, and educational research have socio-economic effects when it comes to tourism. Major negative effects noted including: leakage where resources required by the private sector are not produced locally therefore benefiting other counties, control of tourism assets by non-local, low paid job for local people, loss of land and displacement of the poor, dependency, inflation, increase in social gaps. While on the other hand, the positive effects include: employment, entrepreneurship development, improved standards of living, increase in income, women empowerment, promotional of local arts and culture, positive change in attitude and behavior of locals, increase in education awareness and local pride.

The study further revealed that a significant number of respondents felt that tourism has not met their expectations with many blaming corruption, nepotism, and previous governments but have full confidence that much can be done to improve the industry and benefit locals.

\section{Conclusions}

The study concludes that much still needs to be done to ensure positive socio-economic effects outrides the negatives, much emphasize is to be made on the management side to ensure policies are put in place to address the issues raised. Support from the private sector, and local community is crucial in ensuring that Narok County economy improves and the socio-cultural beliefs and practices of the local community is protected and cherished.

\section{Recommendations}

This study recommends that in order to maximize benefits and minimize negative effects from socio-economic effects of tourism, the following ought to be taken into consideration;

\subsection{Government}

Clear policies should be put in place to ensure leakages, land related issues, unequal distribution of resources and tourism assets, employment, education, empowerment of youth and women, and protection of local arts and culture is addressed and amicable solutions provided. This can be done through: Involving local communities in policy formation and implementation, Setting out financial support for education to increase the chances of local community landing in top jobs, Provide loans and development funds to locals for entrepreneurial purposes especially women and youths to also equally from tourism, Providing title deeds and erecting beacons to ensure that local communities land is protected, Address employment distribution to ensure that local communities also get some of the top jobs especially Human Resource departments, Acquisition of pattern to ensure local arts and culture is protected and will benefits local community, Improve the infrastructure and develop superstructure especially roads, hospitals, schools, and trading centers.

\subsection{Private Sector}

Ensure local communities are evenly distributed when it comes to employment, empower youth and women by buying goods and services from the community this includes, agricultural products, handicrafts and arts, visiting manyattas for charitable events., Assist the government in developing and improving the infrastructure especially roads, and health services., Reviewing remunerations and benefits to employees. This can be done by standardizing the salaries, providing insurance cover, and review of working hours and workers leave.

\subsection{Local Community}

Ensure they participate in tourism related activities by supporting the government and private sector where necessary, Encouraging the youths to pursue education and change some of the traditional ways of life especially over-reliance on tourism activities by tapping into business opportunities, farming in small scale in fertile soil areas near the rivers., Women should participate more in workshops to acquire knowledge and skills for business through formation of groups to enable them access government and private loans and support funds.

\section{REFERENCES}

[1] Andereck, K. L., Valentine, K. M., Knopf, R. C., \& Vogt, C. 
A. (2005). Residents' perceptions of community tourism impacts. Annals of tourism research, 32(4), 1056-1076.

[2] Badan, B.S., \& Bhatt, H. (2007). Sustainable Tourism. New Delhi: Commonwealth Publishers.

[3] Bhandari, M., \& Phd, D. (2014). Is Tourism Always Beneficial? A Case Study from Maasai Mara National Reserve, Narok, Kenya. Pacific Journal of Science and Technology, 15(1), 458-483.

[4] Blake, A., Arbache, J. S., Sinclair, M. T., \& Teles, V. (2008). Tourism and poverty relief. Annals of Tourism Research, $35(1), 107-126$.

[5] Brohman, J. (1996). New directions in tourism for third world development. Annals of tourism research, 23(1), 48-70.

[6] CAmillo, A. A., MinguzzI, A., PRESEnZA, A., \& HOLT, S. (2015). Natural Environmental Sustainability and Micro-Tourism Destinations: The Case of Southern Italy. Sustainability, Social Responsibility, and Innovations in the Hospitality Industry, 267.

[7] Cohen, E. (1984). The sociology of tourism: approaches, issues, and findings. Annual review of sociology, 373-392.

[8] Department of Primary Industries Parks Water and Environment. (2015). Annual Report 2015.

[9] Dixon, J.A., \& Sherman, P.B. (1991). Economics of protected areas: a new look at benefits and costs. Earthscan, London.

[10] Doğan, H. Z. (1989). Forms of adjustment: Sociocultural impacts of tourism. Annals of tourism research, 16(2), 216-236.

[11] Fennell, D.A. (1999) Ecotourism, Routledge: London

[12] Government of Kenya. (2007). Kenya Vision 2030 - A Globally Competitive and Prosperous Kenya, (October), 1180 .

[13] Hall, D., \& Richards, G. (2000). Tourism and sustainable community development. Abingdon: Routledge.

[14] Impact, E. (2015). Travel \& Tourism.

[15] Kim, K., Uysal, M., \& Sirg, M.J. (2012). How does tourism in a community impact the quality of life of community residents? Tourism Management, in press.

[16] Lankford, S. V., \& Howard, D. R. (1994). Developing a tourism impact attitude scale. Annals of tourism research, 21(1), 121-139.Brougham, J., \& Butler, R. W. (1981). A segmentation analysis of resident attitudes to the social impact of tourism. Annals of tourism research, 8(4), $569-590$

[17] Mamhoori, A. (2015). Sustainable tourism development: an empirical survey of tour operators in India. Journal of Tourism and Hospitality, 4(5).
[18] Mathieson, A., \& Wall, G. (1982). Tourism, economic, physical and social impacts. Tourism, economic, physical and social impacts. Longman.

[19] Mbaiwa, J. E. (2005). Enclave tourism and its socio-economic impacts in the Okavango Delta, Botswana. Tourism Management, 26(2), 157-172.

[20] McGehee, N.G., \& Andereck, K. (2004). Factors Influencing Rural Resident's Support of Tourism, Journal of Travel Research, 43(2), 131 - 140.

[21] Nyaupane, G. P., \& Poudel, S. (2011). Linkages among biodiversity, livelihood, and tourism, Annals of Tourism Research, 38(4), 1344-1366.

[22] Okazaki, E. (2008). A community - based tourism model: Its conception and use, Journal of Sustainable Tourism, $16(5), 511-529$.

[23] Pfohl, S.J. (1994). Images of deviance and social control: A sociological history. New York: McGraw - Hill.

[24] Pizam, A. (1978). Tourism's impacts: The social costs to the destination community as perceived by its residents. Journal of travel research, 16(4), 8-12.

[25] Rogerson, C. M., \& Rogerson, J. M. (2010). Local economic development in Africa: global context and research directions. Development Southern Africa, 27, 465 - 480.

[26] Roseland, M. (2005). Towards sustainable communities: Resources for citizen and their governments. Gabriola Island: New Society Publishers.

[27] Sandbrook, C.G. (2010). Putting leakage in its place: the significance of retained tourism revenue in the local context in rural Uganda. Journal of International Development, 22, $124-136$

[28] Scheyvens, R. (1999). Ecotourism and the empowerment of local communities. Tourism Management, 20, 245-249.

[29] Scheyvens, R. (1999). Ecotourism and the empowerment of local communities. Tourism management, 20(2), 245-249.

[30] Sebele, L.S. (2010). Community - based tourism ventures, benefits and challenges: Khama Rhino Sanctuary Trust, Central District, Botswana. Tourism Management, 31, $136-146$.

[31] Shaw, G., \& Williams, A. M. (1994). Critical issues in tourism: a geographical perspective. Critical issues in tourism: a geographical perspective. Blackwell Publishers.

[32] Tosun, C. (2006). Expected nature of community participation in tourism development, Tourism Management, $27,493-504$.

[33] Wagner, J. E. (1997). Estimating the economic impacts of tourism. Annals of Tourism Research, 24(3), 592-608.

[34] Yousuf, A., \& Lal, R. (2013). The impact of Asean on tourism. International Journal of Networking and Parallel Computing, 2(3), 38-44. 